\title{
Presence of Infectious Hypodermal and Haematopoietic Necrosis Virus (IHHNV) in Native Shrimps from Southern Mexico
}

\author{
Ariadne Hernández-Pérez ${ }^{1}$, Jesús Alejandro Zamora-Briseño ${ }^{1}$, Juan Antonio Pérez Vega ${ }^{1}$, \\ Richard Juan de Dios Mena-Loria ${ }^{1}$, Daniel Coronado-Molina² ${ }^{2}$ Jorge Hernández-López², \\ Norma Angelica-López-Téllez ${ }^{3}$, Rossanna Rodríguez-Canul ${ }^{*}$
${ }^{1}$ Laboratorio de Inmunología y Biología Molecular, Centro de Investigación y de Estudios Avanzados del IPN (CINVESTAV-IPN) Unidad Mérida, Yucatán, México
${ }^{2}$ Centro de Investigaciones Biológicas del Noroeste, Sonora, México
${ }^{3}$ Centro Regional de Investigación Pesquera de Lerma, Campeche, Instituto Nacional de la Pesca (CRIP Lerma-INP), Campeche, México
Email: *rossana.rodriguez@cinvestav.mx

How to cite this paper: Hernández-Pérez, A., Zamora-Briseño, J.A., Pérez Vega, J.A., de Dios Mena-Loria, R.J., Coronado-Molina, D., Hernández-López, J., Angelica-LópezTéllez, N. and Rodríguez-Canul, R. (2017) Presence of Infectious Hypodermal and Haematopoietic Necrosis Virus (IHHNV) in Native Shrimps from Southern Mexico. Open Journal of Marine Science, 7, 424432.

https://doi.org/10.4236/ojms.2017.73029

Received: June 20, 2017

Accepted: July 24, 2017

Published: July 27, 2017

Copyright $\odot 2017$ by authors and Scientific Research Publishing Inc. This work is licensed under the Creative Commons Attribution International License (CC BY 4.0). http://creativecommons.org/licenses/by/4.0/

\begin{abstract}
A survey for Infectious Hypodermal and Haematopoietic Necrosis Virus (IHHNV) and White Spot Syndrome Virus (WSSV) was performed during two catching seasons of native shrimps in the Yucatan Coast in the Gulf of Mexico. The mtDNA COI barcode identified two endemic species; the southern pink shrimp Penaeus notialis (Pérez Fantante, 1967) and the northern pink shrimp Penaeus brasiliensis (Latreille, 1987) (previously described as Farfantepenaeus brasiliensis). The prevalence of IHHNV was of $18.18 \%$ in 2016, and of $8.57 \%$ in 2017. All organisms tested negative for WSSV. This is the first identification of wild shrimps in the state of Yucatan Mexico by mtDNA COI barcode as well as the first identification of IHHNV in such species. The presence of IHHNV in wild shrimps populations has a potential of persisting in the coast of Yucatan with putative detrimental effect on local fisheries because once established in natural waters and hosts; such pathogens are almost impossible to eradicate.
\end{abstract}

\section{Keywords}

IHHNV, WSSV, mtDNA COI Barcode, Penaeus notialis, Penaeus brasiliensis, Yucatan Peninsula

\section{Introduction}

The small-scale local fishery for shrimps and prawns supports the income of lo- 
cal fisheries of the Yucatan Peninsula [1]. In this artisanal fishery, there is little bycatch and limited disruption to the benthic (bottom) habitat. This strategy produces high-quality shrimp with minimal adverse impacts on the local ecosystem [2]. The Mexican government regulates this fishery by way of established fishing seasons and gear restrictions [1]. These restriction protocols help to protect its long-term sustainability. However, the main concern is the sanitary status of native shrimps along the coast of the Yucatan Peninsula.

In Mexico, the shrimp farming industry started in 1983 in the state of Sonora located in northwestern Mexico with the broad culture of the blue shrimp Penaeus stylirostris (Stimpson, 1871) [1] [3]. In 1990, this industry suffered severe epizootics being the causative agent the Infectious Hypodermal and Haematopoietic Necrosis Virus (IHHNV). Mexico lost US $\$ 25$ million due to IHHNV infections in the blue shrimp P. stylirostris in the late 1980s/early 1990s [2]. This species was replaced by the Pacific white shrimp Penaeus vannamei (Boone, 1931) due to its resistance to IHHNV infections; in this species, IHHNV causes dwarfism and deformities, but no mortality [4] [5]. However, in 2001, another outbreak occurred with the arrival of the White Spot Syndrome Virus (WSSV). From that date onwards, the shrimp industry struggled huge financial losses due to high mortalities related to WSSV, and by 2009 the shrimp production raised up to a steady production of $\approx 134,000$ tons [2]. However, in 2010 a new WSSV outbreak caused mortality in $60 \%$ of the national production, and since then, shrimp production is recovering slowly.

IHHNV and WSSV are listed since 1997 as notifiable diseases by the World Organization for Animal Health (OIE) [6]. The Aquatic Animal Health Code recommends the detection of these viral agents by PCR and the IQ2000 $0^{\text {in }}$ kit has proven to be reliable test. Both IHHNV and WSSV infect tissues of ectodermal and mesodermal origin. Thus the hemolymph represents a suitable tissue for detection of both viruses [7] [8]. In this way, a rapid and accurate diagnosis of the disease should be established either for disease detection, as well as, to monitor wild species co-habiting along the shrimp farms [6]. In Mexico, similar to other countries, the role of aquaculture in harboring and spreading disease in the aquatic environment has become evident. For example, in the Pacific coast of Mexico; WSSV and IHHNV have been detected in wild shrimps from the states of Sonora and Sinaloa [9], as well as in Nayarit with prevalences up to $45.5 \%$ [10]. While in the Gulf of Mexico, there is only one report of IHHNV in wild species from the state of Tamaulipas located in northeastern Mexico with prevalences of 4.4\% reported in 2005 and 2006 [11]. In all cases, the studies refer that the proximity of the shrimp farms near to the coast could be a risk for the transmission of pathogens [9] [10] [11]. In this sense, the shrimp farming is null or incipient along the shores of the Yucatan Peninsula. Thus, the objectives of this study were first to use the COI DNA-barcoding as a fingerprint to assess the sustainability of the local caching during 2016 and 2017 and second to survey for the presence of IHHNV and WSSV in these wild shrimp populations from southern Mexico. 


\section{Material and Methods}

\subsection{Sample Collection}

Wild shrimps were collected from Progreso, Yucatan (Latitude: $21.261196^{\circ} \mathrm{N}$; Longitude: $89.704264^{\circ} \mathrm{W}$ ) in March 2016 and 2017. This area is used by local fishermen for a small-scale fishery and local trading. Shrimps were collected during the routine fishing of local fishermen, using the fishing gear known as passive mesh net. The number of collected organisms $(\approx 30)$ was according to the OIE recommendations implemented for surveillance of exotic pathogens [12]. Thirty-three organisms were collected in 2016, and 35 organisms were collected in 2017. Once collected, the organisms were separated and maintained alive in $30 \mathrm{~L}$ tanks. Juveniles of $9.4 \mathrm{~g}( \pm 1.27)$ from the catching season of 2016 and juveniles of $8.7 \mathrm{~g}( \pm 2.14)$ from the catching season of 2017 were sampled. $300 \mu \mathrm{L}$ of hemolymph were collected individually from its ventral sinus, with $600 \mu \mathrm{L}$ of anticoagulant solution $(\mathrm{NaCl} 450 \mathrm{mM}, \mathrm{KCl} 10 \mathrm{mM}$, HEPES $10 \mathrm{mM}$, EDTA 10 $\mathrm{mM})$. The samples were fixed with absolute alcohol in 1:1 ratio and transported to the CINVESTAV facilities. In the laboratory, the samples were centrifuged for $5 \mathrm{~min}$ at $2,500 \times \mathrm{g}$ and at $4^{\circ} \mathrm{C}$. The supernatant was discarded, and the cell pellet was used to subsequent gDNA isolation.

\subsection{Molecular Analysis}

\subsubsection{Species Identification}

Genomic DNA was extracted using the Quick-DNA ${ }^{\text {ma }}$ Universal Kit by the manufacturer's protocols. A partial mitochondrial COI sequence (barcoding fragment) was amplified using the primers LCO1490: 5'-ggtcaacaaatcataaagatattgg-3' and HC02198: 5'-taaacttcagggtgaccaaaaaatca-3' [13]. Each $15 \mu \mathrm{L}$ reaction volume contained 1X DreamTaq Green PCR Master Mix (Thermo Scientific ${ }^{\circledR}$ ), 0.25 mM of each primer, and $0.5 \mu \mathrm{L}$ of gDNA (5 - $60 \mathrm{ng}$ ). PCRs were conducted as follows: an initial denaturation step of $94^{\circ} \mathrm{C}$ for $3 \mathrm{~min}$, followed by 34 amplification cycles $\left(94^{\circ} \mathrm{C}\right.$ for $30 \mathrm{~s}, 50^{\circ} \mathrm{C}$ for $30 \mathrm{~s}$, and $72^{\circ} \mathrm{C}$ for $1 \mathrm{~min}$ ) and a final extension of $72^{\circ} \mathrm{C}$ for $5 \mathrm{~min}$. Amplicons were resolved in 1.5\% agarose gel, stained with GeIRed $^{\oplus}$. Confirmed amplicons were diluted 1:1 with nuclease-free water and sequenced in the forward direction by the Sanger method. Sequences were edited, trimmed, and aligned manually in MEGA version 6.0 [14] and blasted against the NCBI data bank (GenBank ${ }^{\mathrm{Tm}}$ ) as well as the BOLD system repository. All sequences were placed in the $\left(G_{e n B a n k}{ }^{\text {tx }}\right)$. See Table 1 for the reference numbers.

\subsubsection{Detection of IHHNV and WSSV}

The molecular detection of IHHNV and WSSV was done in each shrimp using a final point PCR-IQ2000 ${ }^{\text {in }}$ kit following the manufacturer's instructions. The WSSV was also screened by real-time $\mathrm{qPCR}$ using the IQ $\mathrm{SYBR}^{\circ}$ green supermix kit (Biorad) and the primers Ie1-126 F (5'-tgaaacggtgtgctgttagc-3') and Ie1-R ( $5^{\prime}$-aagttcctccatcgtcatcg-3'), for the immediately early WSSV gene amplification, which produce an amplicon of $126 \mathrm{bp}$, according to the following protocol: $60 \mathrm{~s}$ 
Table 1. Species identification and IHHNV and WSSV detection for 2016 and 2017 in Yucatan coast. ND = not detected; D = detected.

\begin{tabular}{|c|c|c|c|c|c|c|c|c|c|}
\hline \multirow{3}{*}{ Species } & \multicolumn{4}{|l|}{2016} & \multicolumn{5}{|c|}{2017} \\
\hline & \multirow{2}{*}{$\begin{array}{c}\text { GenBank } \\
\text { Accesion } \\
\text { number }\end{array}$} & \multicolumn{2}{|c|}{ WSDV } & \multirow{2}{*}{$\begin{array}{l}\text { IHHNV } \\
\text { IQ2000 }\end{array}$} & \multirow{2}{*}{ Species } & \multirow{2}{*}{$\begin{array}{c}\text { Genebank } \\
\text { Accesion } \\
\text { number }\end{array}$} & \multicolumn{2}{|c|}{ WSDV } & \multirow{2}{*}{$\begin{array}{l}\text { IHHNV } \\
\text { IQ2000" }\end{array}$} \\
\hline & & Ie1-126 & IQ2000 ${ }^{\text {TM }}$ & & & & Ie1-126 & IQ2000 ${ }^{\mathrm{Tm}}$ & \\
\hline Penaeus notialis & MF287097 & $\mathrm{ND}$ & ND & ND & Penaeus notialis & MF287130 & ND & $\mathrm{ND}$ & ND \\
\hline Penaeus notialis & MF287098 & ND & ND & ND & Penaeus notialis & MF287131 & ND & ND & ND \\
\hline Penaeus notialis & MF287099 & ND & ND & ND & Penaeus notialis & MF287132 & ND & ND & ND \\
\hline Penaeus notialis & MF287100 & ND & ND & ND & Farfantepenaeus brasiliensis & MF287133 & ND & ND & ND \\
\hline Farfantepenaeus brasiliensis & MF287101 & ND & ND & ND & Farfantepenaeus brasiliensis & MF287134 & ND & ND & ND \\
\hline Penaeus notialis & MF287102 & ND & ND & $\mathrm{D}$ & Farfantepenaeus brasiliensis & MF287135 & ND & ND & ND \\
\hline Penaeus notialis & MF287103 & ND & ND & ND & Farfantepenaeus brasiliensis & MF287136 & ND & $\mathrm{ND}$ & ND \\
\hline Penaeus notialis & MF287104 & ND & ND & ND & Farfantepenaeus brasiliensis & MF287137 & ND & ND & $\mathrm{D}$ \\
\hline Farfantepenaeus brasiliensis & MF287105 & ND & ND & ND & Penaeus notialis & MF287138 & ND & ND & ND \\
\hline Penaeus notialis & MF287106 & ND & ND & ND & Penaeus notialis & MF287139 & ND & ND & ND \\
\hline Penaeus notialis & MF287107 & ND & ND & ND & Penaeus notialis & MF287140 & ND & ND & ND \\
\hline Penaeus notialis & MF287108 & ND & ND & ND & Penaeus notialis & MF287141 & ND & ND & ND \\
\hline Farfantepenaeus brasiliensis & MF287109 & ND & ND & $\mathrm{D}$ & Farfantepenaeus brasiliensis & MF287142 & ND & ND & ND \\
\hline Penaeus notialis & MF287110 & ND & ND & $\mathrm{D}$ & Farfantepenaeus brasiliensis & MF287143 & ND & ND & ND \\
\hline Farfantepenaeus brasiliensis & MF287111 & ND & ND & $\mathrm{D}$ & Farfantepenaeus brasiliensis & MF287144 & ND & ND & ND \\
\hline Penaeus notialis & MF287112 & ND & ND & ND & Farfantepenaeus brasiliensis & MF287145 & ND & ND & ND \\
\hline Penaeus notialis & MF287113 & ND & ND & ND & Penaeus notialis & MF287146 & ND & ND & ND \\
\hline Farfantepenaeus brasiliensis & MF287114 & ND & ND & ND & Penaeus notialis & MF287147 & ND & ND & ND \\
\hline Penaeus notialis & MF287115 & ND & ND & ND & Penaeus notialis & MF287148 & ND & ND & ND \\
\hline Farfantepenaeus brasiliensis & MF287116 & ND & ND & ND & Farfantepenaeus brasiliensis & MF287149 & ND & ND & ND \\
\hline Penaeus notialis & MF287117 & ND & ND & ND & Penaeus notialis & MF287150 & ND & ND & ND \\
\hline Farfantepenaeus brasiliensis & MF287118 & ND & ND & ND & Farfantepenaeus brasiliensis & MF287151 & ND & ND & ND \\
\hline Penaeus notialis & MF287119 & ND & ND & ND & Penaeus notialis & MF287152 & ND & ND & ND \\
\hline Penaeus notialis & MF287120 & ND & ND & ND & Penaeus notialis & MF287153 & ND & ND & ND \\
\hline Farfantepenaeus brasiliensis & MF287121 & ND & ND & ND & Penaeus notialis & MF287154 & ND & ND & ND \\
\hline Farfantepenaeus brasiliensis & MF287122 & ND & ND & $\mathrm{D}$ & Penaeus notialis & MF287155 & ND & ND & ND \\
\hline Penaeus notialis & MF287123 & ND & ND & ND & Penaeus notialis & MF287156 & ND & ND & $\mathrm{D}$ \\
\hline Penaeus notialis & MF287124 & ND & ND & ND & Farfantepenaeus brasiliensis & MF287157 & ND & ND & ND \\
\hline Penaeus notialis & MF287125 & ND & ND & ND & Farfantepenaeus brasiliensis & MF287158 & ND & ND & ND \\
\hline Penaeus notialis & MF287126 & ND & ND & ND & Farfantepenaeus brasiliensis & MF287159 & ND & ND & ND \\
\hline Farfantepenaeus brasiliensis & MF287127 & ND & ND & ND & Penaeus notialis & MF287160 & ND & ND & $\mathrm{D}$ \\
\hline \multirow[t]{2}{*}{ Penaeus notialis } & MF287128 & ND & ND & ND & Farfantepenaeus brasiliensis & MF287161 & ND & ND & ND \\
\hline & & & & & Penaeus notialis & MF287162 & ND & ND & ND \\
\hline \multirow[t]{2}{*}{ Penaeus notialis } & MF287129 & ND & ND & $\mathrm{D}$ & Farfantepenaeus brasiliensis & MF287163 & ND & $\mathrm{ND}$ & ND \\
\hline & & & & & Penaeus notialis & MF287164 & ND & ND & ND \\
\hline
\end{tabular}


at $60^{\circ} \mathrm{C}, 2 \mathrm{~min}$ at $94^{\circ} \mathrm{C}, 40 \mathrm{cycles}$ of $45 \mathrm{~s}$ at $94^{\circ} \mathrm{C}, 45 \mathrm{~s}$ at $60^{\circ} \mathrm{C}$, and finally $7 \mathrm{~min}$ at $72^{\circ} \mathrm{C}$.

The prevalence was reported as the proportion of infected individuals among the total number of sampled organisms per year.

\section{Results}

A total of 68 organisms were collected during the catching seasons of 2016 and 2017. None of the sampled organisms showed physical signs of the disease RDS "runt deformity syndrome," in the rostrum and cuticular deformities [15]. The shrimp's DNA sequences caught in 2016 and 2017 showed the predominance of two species in the port of Progreso; the southern pink shrimp P. notialis and the northern pink shrimp $P$. brasiliensis. The mtCOI DNA sequences were submitted to the GenBank ${ }^{\mathrm{Tm}}$ and the results are shown in Table 1, observing a proportion of $69.6 \%$ for $P$. notialis and $30.3 \%$ for P. brasiliensis in 2016. Moreover, in 2017 a proportion of $54.2 \%$ of $P$. notialis and $45.7 \%$ for $P$. brasiliensis were obtained.

The shrimps sampled during both years showed infection with IHHNV but not with WSSV. A prevalence of $13 \%$ was observed for IHHNV in $P$. notialis, while 30\% was detected in F. brasiliensis in 2016. In 2017 the prevalences were $10.5 \%$ and $6.2 \%$ in $P$. notialis and $F$. brasiliensis respectively.

In the case of the WSSV two PCR systems were used; the IQ2000 ${ }^{\mathrm{rm}}$ as well as a a real-time PCR using primers designed to amplify a fragment of the immediately early gene of the virus (Ie1). All organisms were negative to WSSV.

\section{Discussion}

The artisanal shrimp fishery has a social and economic impact in the state of Yucatan [16]. Sustainability of wild species in a given area is always a priority. In this study, both catching seasons were identified by mtDNA COI barcode; the southern pink shrimp $P$. notialis and the northern pink shrimp P. brasiliensis. Both species are native in the Gulf of Mexico and inhabit naturally in lagoons and coasts of Yucatan. They are of commercial importance for the local fisheries [17] [18]. In this study, both species were positive by PCR for IHHNV with prevalences of $18.18 \%$ and $8.57 \%$ for 2016 and 2017 respectively, as well as the absence of WSSV. No physical signs of the disease like RDS "runt deformity syndrome", rostrum and cuticular deformities or dwarfism [15] were found in the sampled organisms. The sample size was in accordance to the OIE for monitoring viral infections as well as the use of the IQ2000 ${ }^{\mathrm{TM}}[12]$. The IQ2000 test has been validated all around the world and includes an internal DNA control. Thus, the risk of having a false positive result is remote. In this case to confirm IHHNV infection, DNA from suspected native shrimps was injected to uninfected $L$. vannamei shrimps following the Koch's postulate (Data not shown).

Shrimp farming in Yucatan is incipient differing to the shrimp industry from the northwest of Mexico were the shrimp farm's fringe is well established and commonly operate at intensive or hiper-intensive levels. In the Mexican Pacific 
Ocean, IHHNV and WSSV have been reported in wild species [9]. IHHNV had up to $45.5 \%$ of prevalence in wild species in the state of Nayarit [10]. And, in Sonora and Sinaloa, the prevalences of IHHNV were up to $19.5 \%$ between 2008 and 2009 [9]. Furthermore in the Gulf of Mexico, IHHNV has been reportedin Tamaulipas in Farfantepenaeus aztecus (Ives, 1891) and Litopenaeus setiferus (Linnaeus, 1767) with prevalences of 4.4\% between 2005 and 2006 [11] (Figure 1). Although results from this study are similar to those reported in other regions of Mexico, the presence of IHHNV and WSSV has not been reported before this work in the Yucatan Peninsula [19]. Likewise, this is the first report of IHHNV in P. notialis or P. brasiliensis. In this sense, it is important to address that in Mexico there is only one report of WSSV in wild organisms from the Mexican Pacific Coast [9], and to our knowledge, WSSV is absent in the Gulf of Mexico. Although WSSV was not detected in this study, the surveillance of this pathogen is relevant, because WSSV has been reported in more than 100 species of crustaceans, including numerous wild species [20]. Thus, early detection of a given disease is a key strategy for biosecurity and monitoring [21], because viral infections occur in all stages of the life cycle of the shrimp (eggs, larvae,

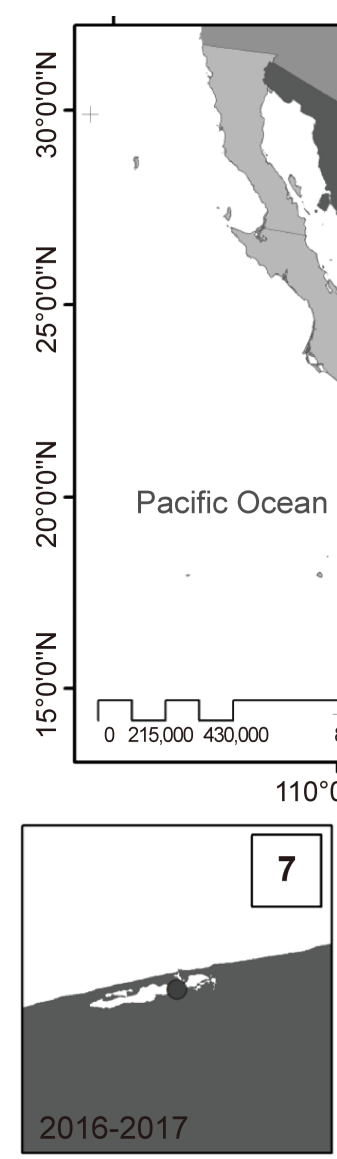

IHHNV $18.18 / 8.57 \%$
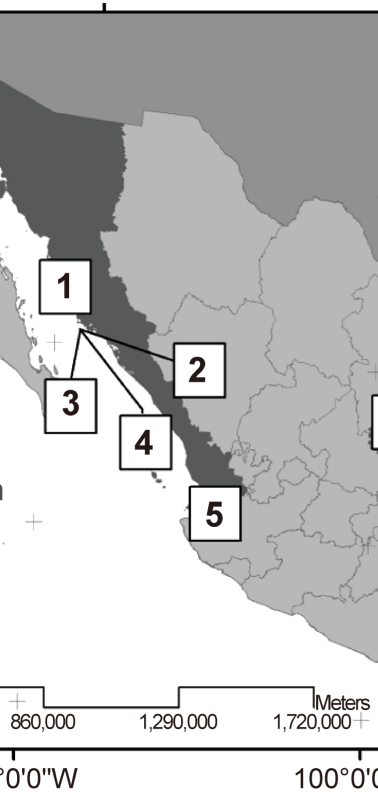

$100^{\circ} 0^{\prime} \mathrm{O}^{\prime \prime} \mathrm{W}$

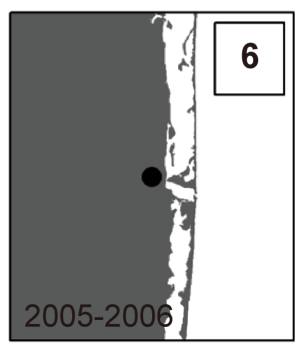

IHHNV 4.4\%

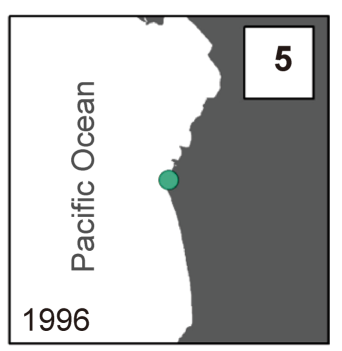

IHHNV 45.5\%
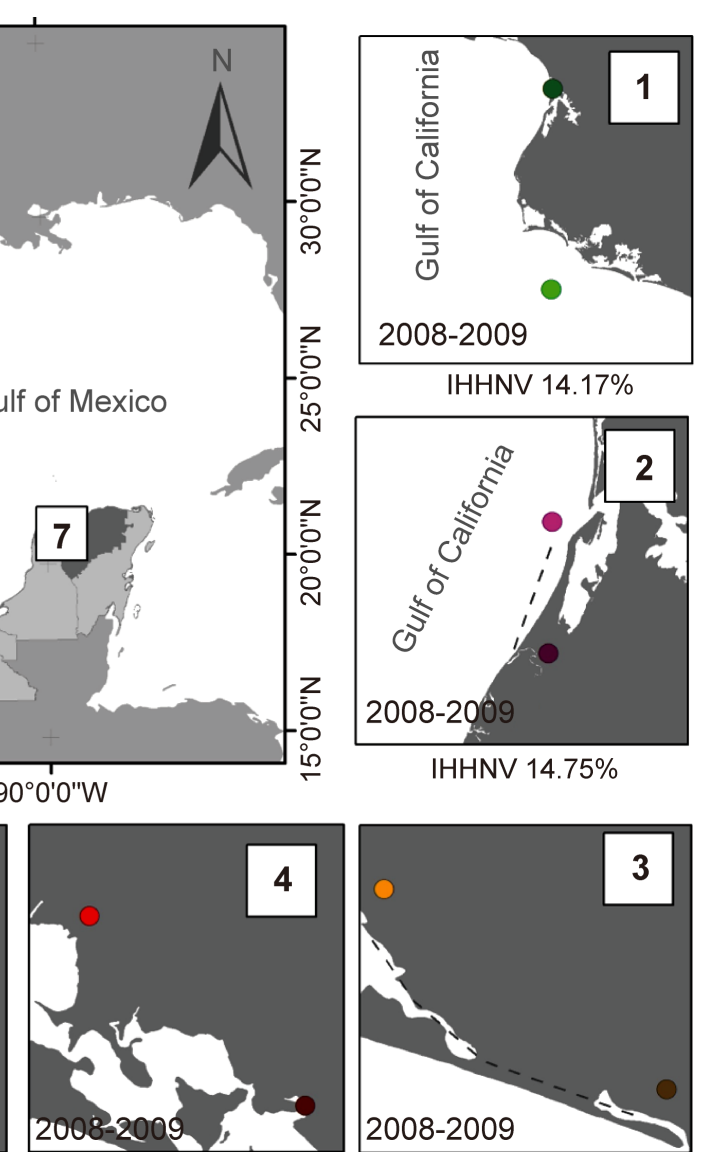

IHHNV 26.18\%

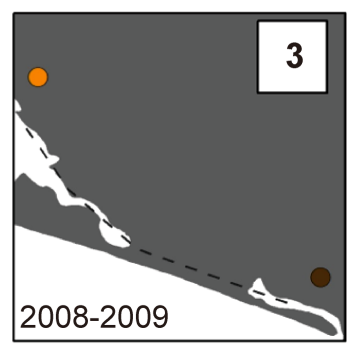

IHHNV 19.14\%

Figure 1. Historic IHHNV prevalence reported in different sites in Mexico: Sites 1 - 5: Wild shrimps collected from the states of Sonora, Sinaloa and Nayarit in the Pacific Ocean. Site 6: Wild shrimps collected from the State of Tamaulipas. Site 7: Progreso, Yucatan in the Gulf of Mexico. For WSSV, prevalences have been reported in sites 1 \& 2. And absent in the Gulf of Mexico. Map was constructed using ArcGIS software version 9.3. Dotted line means fishing transect. 
post-larvae, juvenile, and adults) [21]. In natural conditions is difficult to evidence the effect of a given disease in wild populations [1].

The presence of IHHNV in southern Mexico, support the hypothesis that IHHNV has become an enzootic species in Mexico [22], despite the fact that no major shrimp farms exist in the area. An extension of this study is on its way in a wider area and a wide range of stages to monitor the prevalence of IHHNV and WSSV.

\section{Conclusion}

This study represents the first effort to evaluate the small local shrimp fishery in the coast of the state of Yucatan by mtDNA COI barcode. The presence of IHHNV in two new species provides insight evidence that the virus is enzootic in Mexico. However, more areas need to be surveyed. The absence of WSSV in southern Mexico is of local ecological and economic importance. Long-term monitoring is needed to evaluate the dynamic of prevalences in wild shrimp populations and fisheries.

\section{Acknowledgements}

Special thanks are conveyed to CONACYT for providing a PhD scholarship (No. 369654) to HPA. This research was funded by the external services of the laboratory of Immunology and Molecular Biology CINVESTAV IPN Unidad Merida (Reference number 3587). And Laboratorio de Referencia, Análisis y Diagnóstico de Sanidad Acuícola del Centro de Investigaciones Biológicas del Noroeste S.C. (Reference number15789).

\section{References}

[1] FAO (2016) The State of World Fisheries and Aquaculture 2016. Contributing to Food Security and Nutrition for All. 200 p. http://www.fao.org/3/a-i3720e.pdf

[2] Castro-Cossio, M.A. (2017) Camaronicultura: Historia, avances y retos., in: 1er. Simp. Acuícola Y Pesq. Del Estado Yucatán. http://cesay.org.mx/simposium2017/

[3] Wyban, J. and Sweeney, J.N. (1991) Intensive Shrimp Production Technology: The Oceanic Institute Shrimp Manual. Oceanic Institute Honolulu. https://books.google.com.mx/books/about/Intensive_shrimp_production_technolo gy.html?id=fVAYAQAAIAAJ\&redir_esc=y (accessed March 22, 2017).

[4] Martínez-Cordova, L.R. (1992) Cultured Blue Shrimp (Penaeusstylirostris) Infected with Infectious Hypodermal and Hematopoietic Necrosis Virus in Northwestern Mexico, Progress. Fish-Culturist, 54, 265-266. https://doi.org/10.1577/1548-8640(1992)054<0265:CBSPSI>2.3.CO;2

[5] CONAPESCA, Anuario Estadístico de Acuacultura y Pesca, (2015). http://www.gob.mx/conapesca/documentos/anuario-estadistico-de-acuacultura-y-p esca (accessedFebruary 13, 2017).

[6] Nunan, L.M. and Lightner, D.V. (2011) Optimized PCR Assay for Detection of White Spot Syndrome Virus (WSSV). Journal of Virological Methods, 171, 318 321.

[7] Lo, C.F., Ho, C.H., Chen, C.H., Liu, K.F., Chiu, Y.L., Yeh, P.Y., Peng, S.E., Hsu, H.C., Chang, C.F., Su, M.S., Wang, C.H. and Kou, G.H. (1997) Detection and Tissue 
Tropism of White Spot Syndrome Baculorvisu (WSBV) in Captured Brooders of Penaeus Monodon with Special Emphasis on Reproductive Organs. Diseases of Aquatic Organisms, 30, 53-72. https://doi.org/10.3354/dao030053

[8] Lightner, D. and Redman, R. (1998) Shrimp Diseases and Current Diagnostic Methods. Aquaculture, 164, 201-220.

[9] Macías-Rodríguez, N.A., Mañón-Ríos, N., Romero-Romero, J.L., Camacho-Beltrán, E., Magallanes-Tapia, M.A., Leyva-López, N.E., Hernández-López, J., Magallón-Barajas, F.J., Perez-Enriquez, R., Sánchez-González, S. and Méndez-Lozano, J. (2014) Prevalence of Viral Pathogens WSSV and IHHNV in Wild Organisms at the Pacific Coast of Mexico. Journal of Invertebrate Pathology, 116, 8-12. https://doi.org/10.1016/j.jip.2013.11.002

[10] Morales-Covarrubias, M.S. and Chavez-Sanchez, C. (1999) Histopathological Studies on Wild Broodstock of White Shrimp Penaeus vannamei in the Platanitos Area, Adjacent to San Blas, Nayarit, Mexico. Journal of the World Aquaculture Society, 30, 192-200. https://doi.org/10.1111/j.1749-7345.1999.tb00866.x

[11] Guzmán-Sáenz, F., Molina-Garza, Z.J., Roberto, P.-C., Ibarra-Gámez, J.C. and Galavíz-Silva, L. (2009) Infectious Hypodermal and Hematopoietic Necrosis Virus (IHHNV) and Taura Syndrome Virus (TSV) in Wild Shrimp (Farfantepenaeus aztecus Ives, 1891 and Litopenaeus setiferus Linnaeus, 1767) of La Laguna Madre, Gulf of Mexico. Revista de biología marina y oceanografía, 44, 663-672.

http://www.scielo.cl/scielo.php?pid=S0718-19572009000300012\&script=sci_arttext \&tlng=en

[12] OIE (2010) Aquatic Animal Health Code. 13th Edition. https://www.oie.int/doc/ged/D7821.PDF

[13] Folmer, O., Black, M., Hoeh, W., Lutz, R. and Vrijenhoek, R. (1994) DNA Primers for Amplification of Mitochondrial Cytochrome c Oxidase Subunit I from Diverse Metazoan Invertebrates. Molecular Marine Biology and Biotechnology, 3, 294-299. https://doi.org/10.1371/journal.pone.0013102

[14] Tamura, K., Stecher, G., Peterson, D., Filipski, A. and Kumar, S. (2013) MEGA6: Molecular Evolutionary Genetics Analysis Version 6.0. Molecular Biology and Evolution, 30, 2725-2729. https://doi.org/10.1093/molbev/mst197

[15] May-Kú, M.A., Ordóñez-López, U. and Defeo, O. (2006) Morphometric Differentiation in Small Juveniles of the Pink Spotted Shrimp (Farfantepenaeus brasiliensis) and the Southern Pink Shrimp (F. notialis) in the Yucatan Peninsula, Mexico. Fishery Bulletin, 104, 306-310.

[16] Wakida-Kusunoki, A.T., Rojas-González, R.I., Toro-Ramírez, A., Medina-Quijano, H.A., Cruz-Sánchez, J.L., Santana-Moreno, L.D. and Carrillo-Nolasco, I. (2016) Caracterización de la pesca de camarón en la zona costera de Campeche y Yucatán. Revista Ciência e Pesquisa Unifor, 24, 3-13.

[17] Del Río-Rodríguez, R.E., Pech, D., Soto-Rodriguez, S., Gomez-Solano, M.I. and Sosa-lopez, A. (2013) A Ten-Month Diseases Survey on Wild Litopenaeus setiferus (Decapoda: Penaeidae) fromSouthernGulf of Mexico. Revista de Biología Tropical, 61, 1175-1188. http://www.ncbi.nlm.nih.gov/pubmed/24027916

[18] Sánchez-Paz, A. (2010) White Spot Syndrome Virus: An Overview on an Emergent Concern. Veterinary Research, 41, 43. https://doi.org/10.1051/vetres/2010015

[19] Mendoza-Cano, F. and Sánchez-Paz, A. (2013) Development and Validation of a Quantitative Real-Time Polymerase Chain Assay for Universal Detection of the White Spot Syndrome Virus in Marine Crustaceans. Virology Journal, 10, 186. https://doi.org/10.1186/1743-422X-10-186

[20] Tang, K.F.J. and Lightner, D.V. (2006) Infectious Hypodermal and Hematopoietic 
Necrosis Virus (IHHNV)-Related Sequences in the Genome of the Black Tiger Prawn Penaeus monodon from Africa and Australia. Virus Research, 118, 185-191.

[21] Motte, E., Yugcha, E., Luzardo, J., Castro, F., Leclercq, G., Rodríguez, J., Miranda, P., Borja, O., Serrano, J., Terreros, M., Montalvo, K., Narváez, A., Tenorio, N., Cedeño, V., Mialhe, E. and Boulo, V. (2003) Prevention of IHHNV Vertical Transmission in the White Shrimp Litopenaeus vannamei. Aquaculture, 219, 57-70.

[22] Lightner, D.V., Redman, R.M., Pantoja, C.R., Tang, K.F.J., Noble, B.L., Schofield, P., Navarro, S.A., et al. (2012) Historic Emergence, Impact and Current Status of Shrimp Pathogens in the Americas. Journal of Invertebrate Pathology, 110, 174-183. https://doi.org/10.1016/j.jip.2012.03.006

Submit or recommend next manuscript to SCIRP and we will provide best service for you:

Accepting pre-submission inquiries through Email, Facebook, LinkedIn, Twitter, etc. A wide selection of journals (inclusive of 9 subjects, more than 200 journals)

Providing 24-hour high-quality service

User-friendly online submission system

Fair and swift peer-review system

Efficient typesetting and proofreading procedure

Display of the result of downloads and visits, as well as the number of cited articles Maximum dissemination of your research work

Submit your manuscript at: http://papersubmission.scirp.org/

Or contact ojms@scirp.org 